\title{
Relevance of Additional Immunohistochemical Markers in the Differential Diagnosis of Small B-Cell Lymphomas: A Case-Control Study
}

\author{
Küçük B-Hücreli Lenfomalarda Ek Immünohistokimyasal Belirteçlerin Ayıııı Tanıdaki Yeri: \\ Bir Olgu-Kontrol Çalışması
}

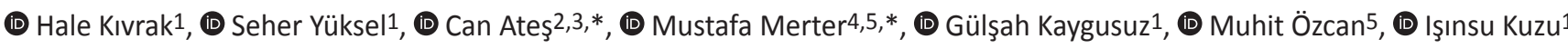 \\ ${ }^{1}$ Ankara University Faculty of Medicine, Department of Pathology, Ankara, Turkey \\ ${ }^{2}$ Aksaray University Faculty of Medicine, Department of Biostatistics and Medical Informatics, Aksaray, Turkey \\ ${ }^{3}$ Ankara University Faculty of Medicine, Department of Biostatistics, Ankara, Turkey \\ ${ }^{4}$ Fırat University Faculty of Medicine, Department of Hematology, Elazığ, Turkey \\ ${ }^{5}$ Ankara University Faculty of Medicine, Department of Hematology, Ankara, Turkey \\ *These two authors were formerly studying at Ankara University in related departments.
}

\section{Abstract}

Objective: Clinical and pathological differential diagnosis of small B-cell lymphomas (SBCLs) is still controversial and may be difficult due to their overlapping morphology, phenotype, and differentiation to plasma cells. We aimed to examine the expression of the immune receptor translocation-associated protein 1 (IRTA1), myeloid cell nuclear differentiation antigen (MNDA), lymphoid enhancer-binding factor-1 (LEF1), and stathmin 1 (STMN1) markers in SBCL cases involving different sites that may have plasma cell differentiation.

Materials and Methods: We studied 154 tissue samples with lymphoma involvement from 116 patients and evaluated the staining distribution of the markers. Expressions were evaluated in 21 chronic lymphocytic leukemia/small lymphocytic lymphoma (CLL/SLL), 7 follicular lymphoma (FL), 14 nodal marginal zone lymphoma, 17 extranodal marginal zone lymphoma, 55 splenic marginal zone lymphoma, 22 marginal zone lymphoma-not otherwise specified, and 18 lymphoplasmacytic lymphoma/Waldenström macroglobulinemia cases by immunohistochemistry.

Results: The results confirmed that LEF1 was the most sensitive and specific marker for CLL/SLL and STMN1 was the most sensitive and specific marker for FL $(p<0.001)$. MNDA and IRTA1 were useful markers to distinguish marginal zone lymphomas.

Conclusion: Our results suggest that LEF1 for CLL/SLL and STMN1 for $\mathrm{FL}$ are reliable markers. LEF1, MNDA, STMN1, and IRTA1 are helpful with other routinely used immunohistochemical markers in a diagnostic algorithm considering their limitations.

Keywords: Small B-cell lymphoma, MNDA, LEF1, Stathmin 1, IRTA1
III

$\mathrm{Oz}$

Amaç: Küçük B-hücreli lenfomaların (SBCL) klinik ve patolojik ayırıcı tanısı halen tartışmalıdır ve örtüşen morfolojileri, fenotipleri ve plazma hücresine farklılaşmaları nedeni ile zorluk yaratabilir. Bu çalışmada plazma hücre farklılaşması gösteren farklı lokalizasyonlardaki SBCL'lerde, immün reseptör translokasyonu ilişkili protein 1 (IRTA1), myeloid hücre farklılaşma antijeni (MNDA), lenfoid güçlendirici bağlama faktörü-1 (LEF1) ve stathmin 1 (STMN1) belirteçlerinin ekspresyonu araştırılmıştır.

Gereç ve Yöntemler: Çalışmada 116 hastadan alınmış olan 154 farklı dokuda belirteçlerin boyanma dağılımları incelenmiştir. Belirteçlerin ekspresyonları 21 kronik lenfositik lösemi/küçük lenfositik lenfoma (KLL/SLL), 7 foliküler lenfoma (FL), 14 nodal marjinal zon lenfoma, 17 ekstranodal marjinal zon lenfoma, 55 splenik marjinal zon lenfoma, 22 marjinal zon lenfoma-başka türlü sınıflandırılamamış ve 18 lenfoplazmasitik lenfoma örneğinde immünhistokimyasal olarak değerlendirilmiş̧tir.

Bulgular: Sonuçlar, LEF1'in KLL/SLL için ve STMN1'in FL için hassas ve spesifik belirteçler olduğunu ( $p$ değeri $<0,001$ ); MNDA ve IRTA1 'in marjinal zon lenfomalarını ayırt etmek için yararlı belirteçler olduğunu gösterdi.

Sonuç: Sonuçlarımız LEF1'in KLL/SLL için ve STMN1'in FL için güvenilir belirleyiciler olduğunu göstermektedir. LEF1, MNDA, STMN1 ve IRTA1, tanısal bir algoritma içinde kısıtıılıkları dikkate alınarak kullanıldığında, rutin olarak kullanılan diğer immünohistokimyasal belirteçlere yardımcıdır.

Anahtar Sözcükler: Küçük B-hücreli lenfoma, MNDA, LEF1, Stathmin 1, IRTA1

${ }^{\circ}$ Copyright 2022 by Turkish Society of Hematology

Turkish Journal of Hematology, Published by Galenos Publishing House

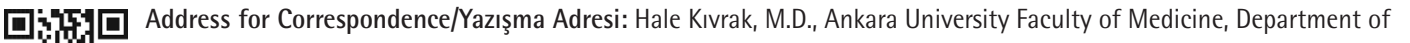




\section{Introduction}

Small B-cell lymphoma (SBCL) entities present indolent clinical behavior and may not be treated at the initial stages. They are theoretically incurable diseases and may progress or transform to aggressive lymphoma during their course. Chronic lymphocytic leukemia/small lymphocytic lymphoma (CLL/SLL), follicular lymphoma (FL), nodal marginal zone lymphoma (NMZL), extranodal marginal zone lymphoma (ENMZL), splenic marginal zone lymphoma (SMZL), lymphoplasmacytic lymphoma/Waldenström macroglobulinemia (LPL/WM), and mantle cell lymphoma (MCL) are the lymphoma entities in this category [1]. MCL should be excluded from the group of SBCLs with its naive B-cell origin, clinical behavior, and different treatment approaches. Differential diagnosis between SBCLs may be challenging. Clinical and radiological findings with histomorphological, immunohistochemical, and molecular data should be evaluated for the correct diagnosis.

Molecular characteristics support the differential diagnosis, such as $I G H / B C L 2$ rearrangement in $\mathrm{FL}$, MYD88 mutation in $\mathrm{LPL} / \mathrm{WM}$, or $I G H / B C L 1$ rearrangement causing cyclin D1 expression in MCL [1]. On the other hand, some markers that are often expected for CLL/SLL and MCL, such as aberrant CD5 expression, may also be found at very low rates in cases of marginal zone lymphomas (MZLs) and LPL/WM based on flow cytometry [2]. Diagnosis of MZL may be challenging since there is no specific marker for the neoplastic cells and diagnosis requires ruling out other possible entities. Clinical presentations such as splenomegaly in SMZL and certain phenotypic and molecular hallmarks in some cases such as BIRC3/MALT1, IGH/MALT1, and IGH/BCL10 translocation in ENMZL or NOTCH2 and KLF2 mutations in SMZL may be helpful in differential diagnosis $[3,4]$, but these molecular findings are not as characteristic and frequent as BCL2 translocation for FL or BCL1 translocation for MCL. In daily clinical practice, a diagnostic approach based on morphology and immunophenotyping is crucial. However, for cases with atypical presentation, unexpected phenotypic characteristics, overlapping morphological features, and especially restrictions related to the amount of tissue may cause misdiagnosis. All SBCLs may be accompanied by plasma cells in different proportions. Plasma cell differentiation with or without paraproteinemia could create difficulty in the differential diagnosis of SBCLs. Especially if the first examined diagnostic material is bone marrow or a core biopsy, the diagnostic approach may be more challenging. Flow cytometry is very helpful but may not be available in every case. Thus, in addition to the standard antigens, there is a need for alternative supportive markers to solve the diagnostic problems of difficult SBCL cases.

Individual studies reveal the role of various antigens expressed at different maturational and functional steps of B cells as well as the lymphomas originating from those cells.
Myeloid cell nuclear differentiation antigen (MNDA) is a human granulocyte monocyte/macrophage-specific nuclear protein initially detected in the late myeloblast and monoblast stages of differentiation [5]. In addition to acute and chronic myeloid leukemia, its expression was also detected in $\mathrm{MCL}$, diffuse large B-cell lymphoma, hairy cell leukemia, and CLL/SLL $[6,7]$. MNDA is accepted as a putative marginal zone marker together with immune receptor translocation-associated protein 1 (IRTA1) [8]. The $55-\mathrm{kDa}$ homodimer CD27 is a member of the tumor necrosis factor receptor family and a key marker for memory $B$ cells that induces their differentiation to plasma cells [9]. It is expressed at different rates in neoplastic cells of all types of MZLs and other SBCLs [10,11]. Lymphoid enhancer-binding factor-1 (LEF1) is a nuclear transcription factor and downstream mediator of the $\mathrm{Wnt} / \beta$-catenin signaling pathway that provides proliferative signals for most progenitor cells in both B-cell and T-cell lineages $[12,13]$. LEF1 positivity in SBCLs is thought to support the diagnosis of CLL/SLL $[1,14,15]$. The IRTA1 gene is located on chromosome 1q21, thought to be involved in B-cell-mediated immune responses and cell migration. It is selectively expressed in B cells of the marginal zone and is therefore considered a marginal zone marker like MNDA, but it has lower sensitivity and higher specificity compared to MNDA [8]. In some studies, IRTA1 is used as a marker for distinguishing MALT lymphoma and NMZL from other SBCLs $[16,17]$. Stathmin 1 (STMN1) is a cytoplasmic protein also known as oncoprotein 18. Its expression was detected in $\mathrm{FL}$, especially when germinal center markers such as CD10 and/or Bcl-6 were negative [18]. It was reported as being very helpful in the distinction between $\mathrm{FL}$ and MZLs in skin [19].

In this study we aimed to screen the distribution of MNDA, IRTA1, LEF1, CD27, and STMN1 expression in various tissues involved in SBCLs to determine their value in differential diagnosis.

\section{Materials and Methods}

\section{Case Selection and Clinical Data}

Cases diagnosed as one of the SBCLs between the years 2006 and 2015 were retrieved from the files of our department for this study.

A total of 517 tissue samples with SBCL involvement were reevaluated based on prior hematoxylin and eosin staining and immunohistochemically stained slides by two authors (HK, IK). The diagnosis was made according to the criteria described in the 2017 World Health Organization (WHO) classification without considering the previous diagnosis. From among these 517 cases, 154 tissue samples from 116 patients were selected based on the availability of adequate tissue in paraffin blocks with other laboratory findings and clinical follow-up. The amount of plasma cells among the neoplastic lymphocytes was also considered. Plasma cells were inherently accompanied by many 
MZL cells. There were also varying proportions of accompanying plasma cells in two of the CLL/SLL and five of the FL cases.

Patients in the MZL group were re-evaluated in light of clinical findings such as organomegaly and B symptoms as well as available laboratory findings such as flow cytometry, mutation status, complete blood count, and protein electrophoresis. Cases were re-grouped as SMZL, NMZL, and ENMZL or as MZLNOS if specification was not possible. Since our institute is a reference center, we were able to examine a considerable amount of splenectomies with SMZL involvement $(n=32)$ and also synchronously involved bone marrow $(n=8)$ and abdominal lymph nodes $(n=5)$ of some of these cases $(n=16)$, which gave us the opportunity to compare expressions in different involved sites.

\section{Immunohistochemistry}

LEF1, MNDA, CD27, IRTA1, and STMN1 expressions were analyzed in formalin-fixed paraffin-embedded tissue sections using the antibodies listed in Table 1. The Ventana Roche automated system (Ventana Medical Systems-Roche, USA) and secondary visualization kits were used according to the manufacturer's instructions. Appropriate positive and negative controls were checked for each antibody.

\section{Interpretation of the Staining}

MNDA expression was evaluated as positive or negative according to the amount of positive neoplastic B-cells. Strongly stained monocytes and macrophages in the microenvironment were used as the internal positive control. Values above a 15\% threshold were considered as positive staining for neoplastic B-cells. The staining for IRTA1 was considered positive when neoplastic cells formed small groups with more than three cells or sheets as described in previous studies [20]. LEF1, STMN1, and CD27 were considered positive when more than $20 \%$ of the neoplastic cells were expressing these markers.

Distributions of the expression patterns of the antigens in normal tissues and cells and the internal positive controls are summarized in Table 2.

\section{Statistical Analysis}

SPSS 20 for Windows (IBM Corp., USA) was used. Continuous variables were given as median (min-max) and categorical variables were given as percentage. The Mann-Whitney $U$ test was used to compare continuous variables between two independent groups. Chi-square and/or Fisher exact tests were used in the analysis of categorical variables. For all statistical comparisons a type- 1 error level $(\alpha)$ below $5 \%(p<0.05)$ was accepted as statistically significant.

\section{Results}

In all diagnostic groups the mean age was 63.75 years (range: 34-90). The mean ages of the patients were consistent with the expected age distribution based on the 2017 WHO criteria. There were no gender differences for any diagnostic groups ( $p>0.05$ ).

Twenty-two MZL samples were reclassified as MZL-NOS due to the involved tissue, morphology, phenotype, and laboratory and clinical features, which did not help in the description of nodal, splenic, or extranodal types. Nine of 18 cases of LPL/WM were confirmed by MYD88 mutation results. The distribution of the cases according to diagnostic groups and localization properties are summarized in Table 3.

\section{Immunohistochemical Analysis}

Results of immunohistochemical analysis are detailed in Table 4.

\begin{tabular}{|l|l|l|l|l|l|l|}
\hline \multicolumn{7}{|l|}{ Table 1. Technical details of the antibodies and immunohistochemistry procedures. } \\
\hline $\begin{array}{l}\text { Antibody (Ab) } \\
\text { against }\end{array}$ & $\begin{array}{l}\text { Antigen retrieval/ } \\
\text { duration }(\mathbf{m i n})\end{array}$ & $\begin{array}{l}\text { Ab incubation } \\
\text { (min) }\end{array}$ & Clone & Dilution & Kit & Supplier \\
\hline LEF1 & EDTA/30 & $\begin{array}{l}\text { Rabbit } \\
\text { monoclonal } \\
\text { EPR2029Y }\end{array}$ & $1 / 200$ & $\begin{array}{l}\text { Biotin-free OptiView DAB } \\
\text { IHC Detection Kit }\end{array}$ & Abcam \\
\hline MNDA & EDTA/60 & 60 & $\begin{array}{l}\text { Mouse } \\
\text { monoclonal 253A }\end{array}$ & $1 / 5$ & $\begin{array}{l}\text { Biotin-free OptiView DAB } \\
\text { IHC Detection Kit }\end{array}$ & Prof. Miguel Piris \\
\hline CD27 & EDTA/60 & 60 & $\begin{array}{l}\text { Mouse } \\
\text { monoclonal } \\
137 B 4\end{array}$ & $1 / 30$ & $\begin{array}{l}\text { Biotin-free OptiView DAB } \\
\text { IHC Detection Kit }\end{array}$ & Acris \\
\hline IRTA1 & EDTA/60 & 40 & $\begin{array}{l}\text { Murine } \\
\text { monoclonal } \\
\text { IRTA1 }\end{array}$ & $1 / 10$ & $\begin{array}{l}\text { Biotin-free OptiView DAB } \\
\text { IHC Detection Kit }\end{array}$ & $\begin{array}{l}\text { Prof. Brunangelo } \\
\text { Falini }\end{array}$ \\
\hline STMN1 & EDTA/60 & 32 & Polyclonal & $1 / 250$ & $\begin{array}{l}\text { Indirect Streptavidin Biotin } \\
\text { iVIEW DAB Detection Kit }\end{array}$ & Abcam \\
\hline LEF1: Lymphoid enhancer-binding factor-1; MNDA: myeloid cell nuclear differentiation antigen; IRTA1: immune receptor translocation-associated protein 1; STMN1: stathmin 1. \\
\hline
\end{tabular}




\section{LEF1 Expression}

Immunohistochemical staining for LEF1 was performed on 154 samples, including $21 \mathrm{CLL} / \mathrm{SLL}, 7$ FL, 18 LPL/WM, 55 SMZL, 14 NMZL, 17 ENMZL, and 22 MZL-NOS cases. Among the 21 samples with CLL/SLL involvement (13 bone marrow and 8 lymph node samples), LEF1 immunostaining demonstrated uniformly strong nuclear positivity of neoplastic cells in 10 cases (47.6\%; $\mathrm{p}<0.001$ ) (Figure 1, Table 4). Only 1 of 10 LEF1-positive patients $(10 \%)$ presented with an atypical phenotype (CD5-negative and/or CD23-negative). Two of the LEF1-negative patients presented with monotypic plasma cell differentiation. There were no significant differences between LEF1 staining patterns for CLL/SLL cases involving different sites for bone marrow or lymph nodes. LEF1 was expressed in 9\% (2/22) of the MZL-NOS cases. We could not compare the T cells by CD3 staining in one case due to the loss of foci in serial sections. LEF1 was negative in all other lymphoma cases.

\section{MNDA and CD27 Expressions}

MNDA and CD27 expressions were parallel, especially for MZL cases. The expressions of these two markers in all diagnostic groups were significant in cases of MZLs ( $p=0.02)$ (Figure 2 ) and CLL/SLL ( $p=0.019)$ (Figure 1, Table 4).

MNDA expression on background macrophages and monocytes was used as an internal positive control. Especially in the bone marrow samples, less intense staining of neoplastic B

Table 2. Expression characteristics of the target antigens in normal hematolymphoid tissues.

\begin{tabular}{|l|l|l|l|l|l|}
\hline Antigen & LEF1 & MNDA & CD27 & STMN1 & IRTA1 \\
\hline Localization & Nucleus & Nucleus & Cytoplasm & Cytoplasm & Cytoplasm \\
\hline Tonsils & T cells & $\begin{array}{l}\text { MZ cells } \\
\text { Monocytes } \\
\text { Macrophages }\end{array}$ & $\begin{array}{l}\text { GC and MZ cells } \\
\text { B cells }\end{array}$ & GC cells & $\begin{array}{l}\text { Underneath and within the } \\
\text { tonsil epithelium }\end{array}$ \\
\hline Spleen & T cells & $\begin{array}{l}\text { MZ cells } \\
\text { Monocytes } \\
\text { Macrophages }\end{array}$ & $\begin{array}{l}\text { GC and MZ cells } \\
\text { B cells }\end{array}$ & GC cells & - \\
\hline Bone marrow & T cells & $\begin{array}{l}\text { Myeloid cells } \\
\text { Monocytes } \\
\text { Macrophages }\end{array}$ & Plasma cells & $\begin{array}{l}\text { Myeloid and erythroid } \\
\text { precursors }\end{array}$ & - \\
\hline Lymph nodes & T cells & $\begin{array}{l}\text { MZ cells } \\
\text { Histiocytes } \\
\text { Macrophages }\end{array}$ & $\begin{array}{l}\text { GC and MZ cells } \\
\text { B cells }\end{array}$ & GC cells & $\begin{array}{l}\text { Monocytoid B-cells, } \\
\text { endothelial cells, sinusoidal } \\
\text { cells }\end{array}$ \\
\hline
\end{tabular}

LEF1: Lymphoid enhancer-binding factor-1; MNDA: myeloid cell nuclear differentiation antigen; IRTA1: immune receptor translocation-associated protein 1; STMN1: stathmin 1; GC: germinal center; MZ: marginal zone.

\begin{tabular}{|c|c|c|c|c|c|c|}
\hline Diagnosis & $n$ & $\%$ & $\begin{array}{l}\text { Spleen, } \\
\text { n (\%) }\end{array}$ & $\begin{array}{l}\text { Bone marrow, } \\
\text { n (\%) }\end{array}$ & $\begin{array}{l}\text { Lymph nodes, n } \\
(\%)\end{array}$ & $\begin{array}{l}\text { Extranodal sites*, } \\
\text { n (\%) }\end{array}$ \\
\hline SMZL & 55 & 36.1 & $23(41.8)$ & $24(43.6)$ & $8(14.5)$ & 0 \\
\hline LPL/WM & 18 & \begin{tabular}{|l|}
11.6 \\
\end{tabular} & 0 & $17(24.3)$ & $1(5.6)$ & 0 \\
\hline MZL-NOS & 22 & 14.2 & 0 & $12(54.5)$ & $9(40.9)$ & $1(4.5)$ \\
\hline NMZL & 14 & 9 & 0 & $3(22.4)$ & $10(71.4)$ & $1(7.1)$ \\
\hline ENMZL & 17 & 11 & 0 & 0 & $1(5.9)$ & 16 (94.1) \\
\hline $\mathrm{FL}$ & 7 & 4.5 & 0 & $1(14.3)$ & $6(85.7)$ & 0 \\
\hline CLL/SLL & 21 & 13.5 & 0 & $13(61.9)$ & $8(38.1)$ & 0 \\
\hline Total samples & 154 & 100 & 23 & 70 & 43 & 18 \\
\hline
\end{tabular}


lymphocytes was considered for the correct interpretation and was helpful in avoiding overinterpretation (Figure 1).

In $69 \%$ of SMZL, $78.6 \%$ of NMZL, $64.7 \%$ of ENMZL, and $63.6 \%$ of MZL-NOS cases, MNDA expression was significant. In 16 of 21 (76\%) CLL/SLL, 5 of 18 (27.7\%) LPL/WM, and 1 of 7 (14\%) FL cases, MNDA was also expressed. Four of 5 MNDA-positive LPL cases were confirmed by their MYD88 mutation status.
Considering the bone marrow infiltrations of different diagnostic groups, MNDA expression was observed in 18 of 24 SMZL (75\%), 8 of 12 MZL-NOS (66.6\%), and 2 of 3 NMZL (66.6\%) cases. The percentage and intensity of MNDA expression in MZL cases were similar for all involved tissues.

\section{STMN1 Expression}

STMN1 was expressed in 5 of 7 (71.4\%) FL, 1 of 55 (1.8\%) SMZL, 1 of $18(5.6 \%)$ LPL/WM, 2 of 22 (9.1\%) MZL-NOS, 1 of 7 (7.1\%)

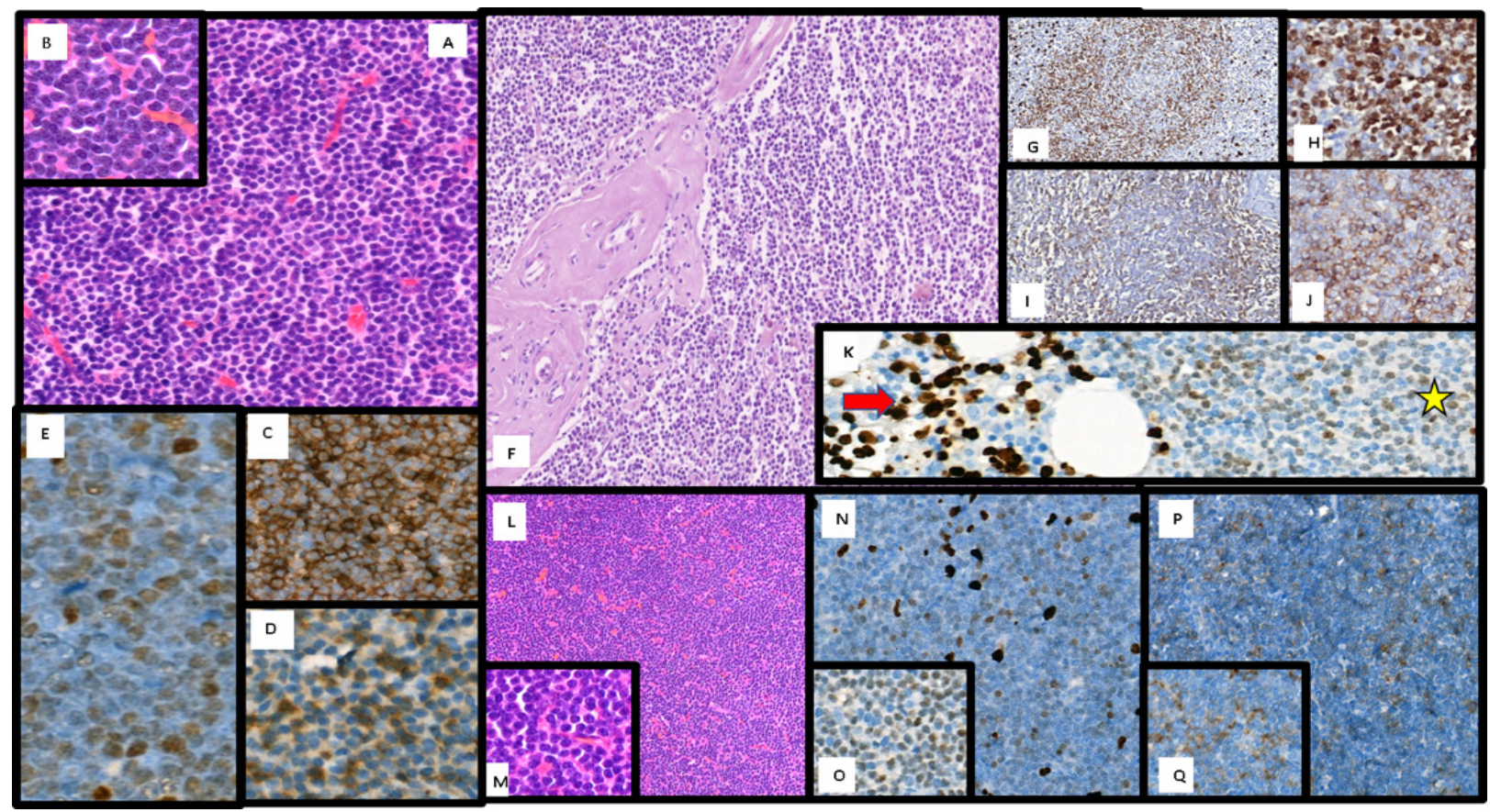

Figure 1. A chronic lymphocytic leukemia/small lymphocytic lymphoma (CLL/SLL) case characterized by monomorphic small mature B cells $(A, B)$ showing typical co-expression of CD5 (C) and CD23 (D) with nuclear LEF1 positivity (E) by immunohistochemistry. A splenic marginal zone lymphoma case with plasma cell differentiation (F). Neoplastic B-lymphoid cells expressed nuclear MNDA (G, H) and cytoplasmic CD27 ( $(, J)$. The staining intensity of macrophages as an internal positive control was strikingly strong (arrow) compared to neoplastic B cells (star) (K). A case of CLL/SLL ( $L, M)$ expressing nuclear MNDA $(N, 0)$ and cytoplasmic CD27 (P, Q).

\begin{tabular}{|c|c|c|c|c|c|c|}
\hline Diagnosis & $n$ & $\begin{array}{l}\text { LEF1, } \\
\%(n)\end{array}$ & $\begin{array}{l}\text { MNDA, } \\
\%(n)\end{array}$ & $\begin{array}{l}\text { CD27, } \\
\%(n)\end{array}$ & \begin{tabular}{|l} 
STMN1, \\
$\%$ (n)
\end{tabular} & \begin{tabular}{|l} 
IRTA1, \\
\% (n)
\end{tabular} \\
\hline SMZL & 55 & $0(0)$ & 69 (38) & $50.9(28)$ & $1.8(1)$ & $1.8(1)$ \\
\hline LPL/WM & 18 & $0(0)$ & $27.7(5)$ & $27.7(5)$ & $5.6(1)$ & $0(0 \%)$ \\
\hline MZL-NOS & 22 & $9.1(2)$ & $63.6(14)$ & $81.8(18)$ & $9.1(2)$ & $4.5(1)$ \\
\hline NMZL & 14 & $0(0)$ & 78 (11) & $71.4(10)$ & $7.1(1)$ & $35.7(5)$ \\
\hline ENMZL & 17 & $0(0)$ & $64.7(11)$ & $70.6(12)$ & $11.7(2)$ & $41.2(7)$ \\
\hline $\mathrm{FL}$ & 7 & $0(0)$ & $14(1)$ & 42.9 (3) & $71.4(5)$ & $0(0 \%)$ \\
\hline CLL/SLL & 21 & $46.7(10)$ & $76(16)$ & $62(13)$ & $57.1(12)^{* *}$ & $0(0 \%)$ \\
\hline $\mathrm{p}^{*}$ & & $<0.001$ (for CLL) & $\begin{array}{l}0.02 \\
\text { (for MZL and CLL) }\end{array}$ & $\begin{array}{l}0.019 \\
\text { (for MZL and CLL) }\end{array}$ & $\begin{array}{l}<0.001 \\
\text { (for FL) }\end{array}$ & $\begin{array}{l}<0.001 \\
\text { (for NMZL and } \\
\text { ENMZL) }\end{array}$ \\
\hline \multicolumn{7}{|c|}{$\begin{array}{l}\text { SMZL: Splenic marginal zone Iymphoma; LPL/WM: Iymphoplasmacytic lymphoma/Waldenström macroglobulinemia; MZL-NOS: marginal zone lymphoma-not otherwise specifie } \\
\text { NMZL: nodal marginal zone Iymphoma; ENMZL: extranodal marginal zone lymphoma; FL: follicular lymphoma; CLL/SLL: chronic lymphocytic leukemia/small lymphocytic Iymphom } \\
\text { LEF1: Iymphoid enhancer-binding factor-1; MNDA: myeloid cell nuclear differentiation antigen; IRTA1: immune receptor translocation-associated protein 1; STMN1: stathmin } 1 . \\
\text { *: The p-values for markers are given only for significant entities. }{ }^{*} \text { : STMN1 positivity was detected only on scattered paraimmunoblastic cells of CLL/SLL cases. }\end{array}$} \\
\hline
\end{tabular}


NMZL, and 2 of 17 (11.7\%) ENMZL cases (Table 4). The number of $\mathrm{FL}$ cases in this study was limited due to the selection of plasma cell-rich cases. STMN1 expression was only significant in FL cases $(p<0.001)$ compared to other entities (Table 4$)$. Interestingly, we observed striking STMN1 expression in 57.1\% of CLL/SLL cases. The staining was selectively restricted on the paraimmunoblastic cells but not on small cell components (Figure 2).

STMN1 was expressed in two of the CD10-negative FL cases, one of which was also BCL2-negative. The $\mathrm{FL}$ cases were accompanied by various amounts of plasma cells in this series and STMN1 was negative on these accompanying plasma cells. STMN1 expression was strictly related to the highly proliferating and transformed cells in other lymphoma cases (Figure 2).

The two STMN1-negative FL cases were both CD10-positive and Bcl-2-positive. They were histological grade 1 or 2 and had a low Ki67 proliferation index $(<10 \%)$.

\section{IRTA1 Expression}

The localizations of 17 ENMZL samples are summarized Table 3. IRTA1 was expressed in 1.8\% (1/55) of SMZL, 4.5\% (1/ 22) of MLNOS, 41.2\% (7/17) of ENMZL, and 35.7\% (5/14) of NMZL cases (Figure 3, Table 4). IRTA1 expression was statistically significant in cases of NMZL and ENMZL $(p<0.001)$. We did not observe IRTA1 expression in concomitant plasma cells in any diagnostic group.

IRTA1 expression was observed in only 1 of 55 SMZL cases. This case showed large cell transformation in the splenectomy material and bone marrow involvement with the small cell component. IRTA1 expression was present in the bone marrow neoplastic B-cell population but not in the spleen.

\section{Plasma Cell Differentiation}

Plasma cells expressed CD27 in all diagnostic groups and were negative for the other markers (Figure 3).

\section{Discussion}

The differential diagnosis of SBCLs may be challenging, especially if they present an atypical phenotype, overlapping features, and plasmocytic differentiation in addition to the limitations of biopsy samples $[1,21]$.

MZLs express CD5 less frequently and do not express CD10. These points are helpful for differential diagnosis from $\mathrm{FL}$ and $\mathrm{CLL/SLL}$, which also have more typical immunophenotypic and molecular features. However, distinguishing follicular

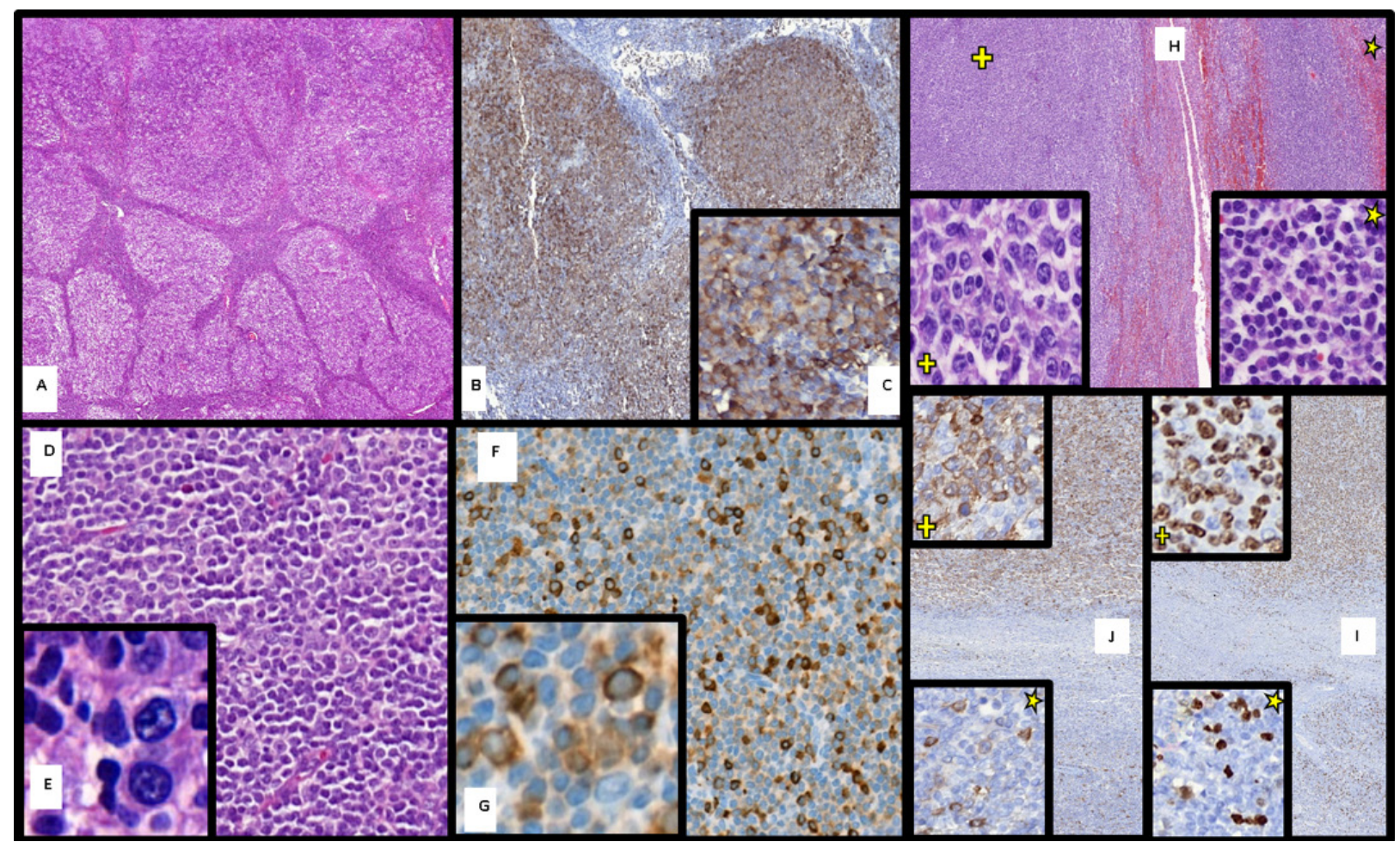

Figure 2. A case of follicular lymphoma with closely packed neoplastic follicles showing a back-to-back pattern (A) with strong cytoplasmic STMN1 expression $(B, C)$ by immunohistochemistry. A chronic lymphocytic leukemia/small lymphocytic lymphoma case ( $D$, E) demonstrating selective STMN1 expression on paraimmunoblasts while small cells were negative $(F, G)$. A case of splenic marginal zone lymphoma $(\mathrm{H})$ with transformation showing small (star) and large (+) cell areas, confirmed by the striking difference of Ki67 proliferation status (I). STMN1 expression is prominent in the large cells (+) compared to the small cells (star) (J). 
colonization in MZL from marginal zone differentiation in $\mathrm{FL}$ is a particularly challenging diagnostic dilemma [22]. Only ENMZL is a well-defined entity in terms of clinicopathologic presentation, genetics, and treatment. NMZL and SMZL share more similar morphologies and molecular alternations [4].

LPL/WM is relatively rare, characterized by immunoglobulin M (IgM)-producing B cells and plasma cells, usually involving the bone marrow and sometimes the lymph nodes or spleen [1]. However, neither morphology nor IgM paraproteinemia can provide a clear distinction from other SBCLs $[23,24]$. About $20 \%$ of SMZLs may produce IgM heavy chain and plasma cell differentiation [25]. Although it is not specific, the MYD88 L265P mutation is highly suggestive of LPL and should be evaluated for diagnosis as a standard procedure. However, this mutation may also be seen in a small proportion of other SBCLs [21]. In our study, MYD88 mutation data were obtained from the hospital records of half of the patients examined. Plasmacytoid/ plasmocytic differentiation and the monoclonal component are frequent in SMZL and NMZL. Therefore, these two entities can be misdiagnosed as LPL. In this study, no statistically significant expression was detected for any of the studied markers in the LPL/WM patients. Four of the five MNDA-positive LPL cases were also confirmed by positive MYD88 mutation results.
LEF1 expression was detected in 70\%-100\% of CLL/SLL and 18\%-38\% of transformed diffuse large B-cell lymphoma cases in different series. Minor positivity was detected in $\mathrm{FL}, \mathrm{MCL}$, LPL, and low-grade and high-grade MZLs. The cut-off value of LEF1 expression was given as 10\% for diagnostic support of CLL with sensitivity of $92 \%$ and specificity of $70 \%$ in other studies $[14,15]$.

Similar to previous studies, we demonstrated the role of LEF1 as a specific and reproducible diagnostic marker for CLL $(p<0.001)$. The loss of LEF1 expression was mentioned in relation to plasma cell differentiation in CLL/SLL [26]. We also saw LEF1-negative cases in our series, but only two of them were accompanied by monotypic plasma cells.

In lymphoid tissues, most of the MNDA-positive cells were located in the marginal zone and few were in the mantle zone [7]. Considering the results of three previous studies, MNDA is expressed in many SBCLs but has the highest rates in MZLs $[7,22,27]$.

Another point of consideration for MNDA is its weak nuclear expression on the naive B-cells of the primary follicles. This should be kept in mind especially while evaluating small biopsies [28]. Another important finding of our study is the significant

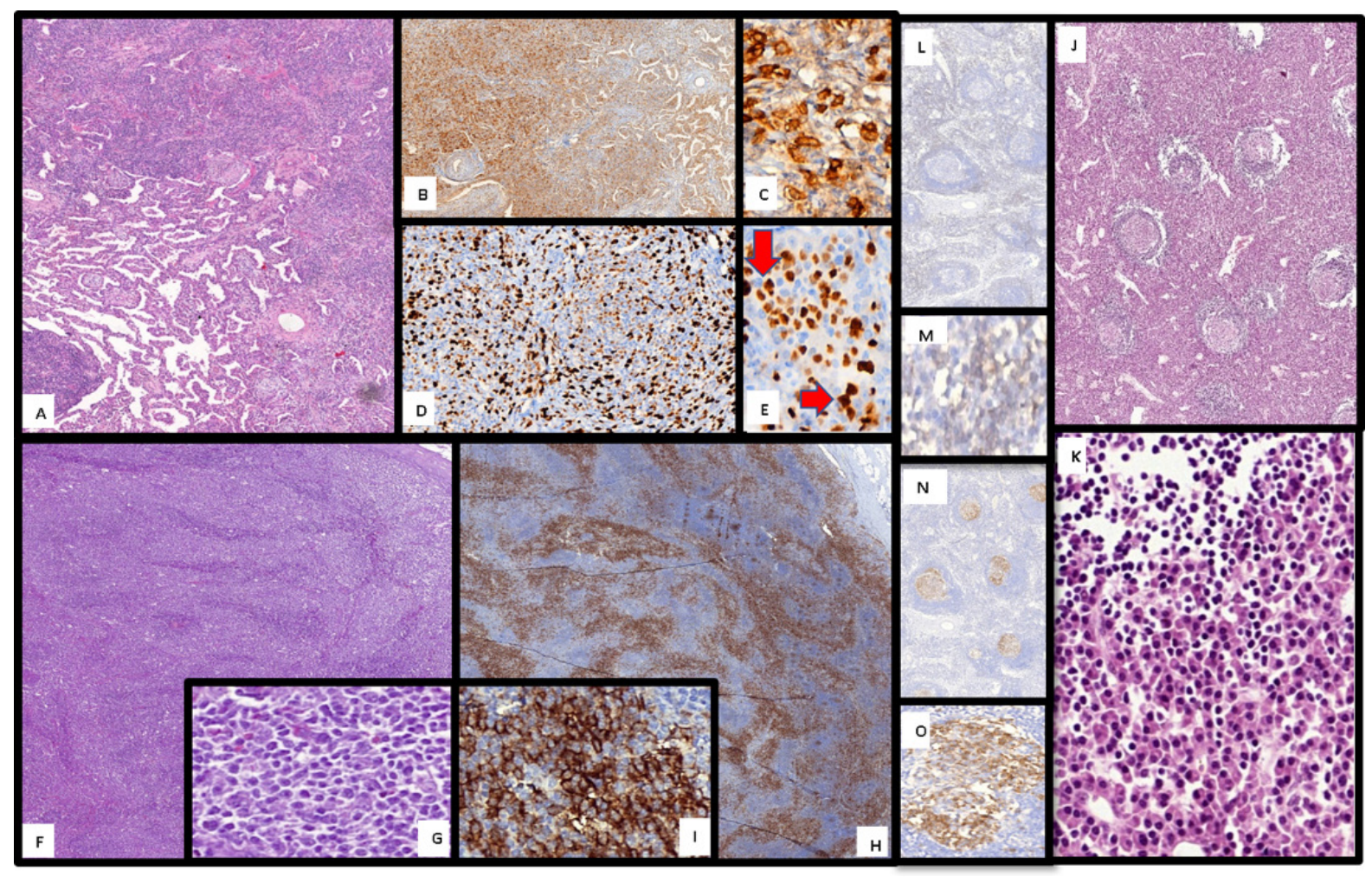

Figure 3. A case of extranodal marginal zone lymphoma of the lungs with neoplastic lymphoid cells infiltrating interstitial areas (A). Diffuse cytoplasmic IRTA1 $(B, C)$ and pale nuclear MNDA-expressing neoplastic lymphoid cells with scattered strong positive histiocytes (arrow) in the background $(D, E)$. A case of nodal marginal zone lymphoma $(F, G)$ with striking sinusoidal infiltration pattern showing strong cytoplasmic expression IRTA1 ( $\mathrm{H}, \mathrm{I})$. A case of B-cell lymphoma with predominant monotypic plasma cell differentiation (J) with striking infiltration of interfollicular areas $(K)$. Only CD27 expression $(L, M)$ was observed in the neoplastic plasma cells. STMN1 $(N, 0)$ was positive on the reactive residual germinal centers. 


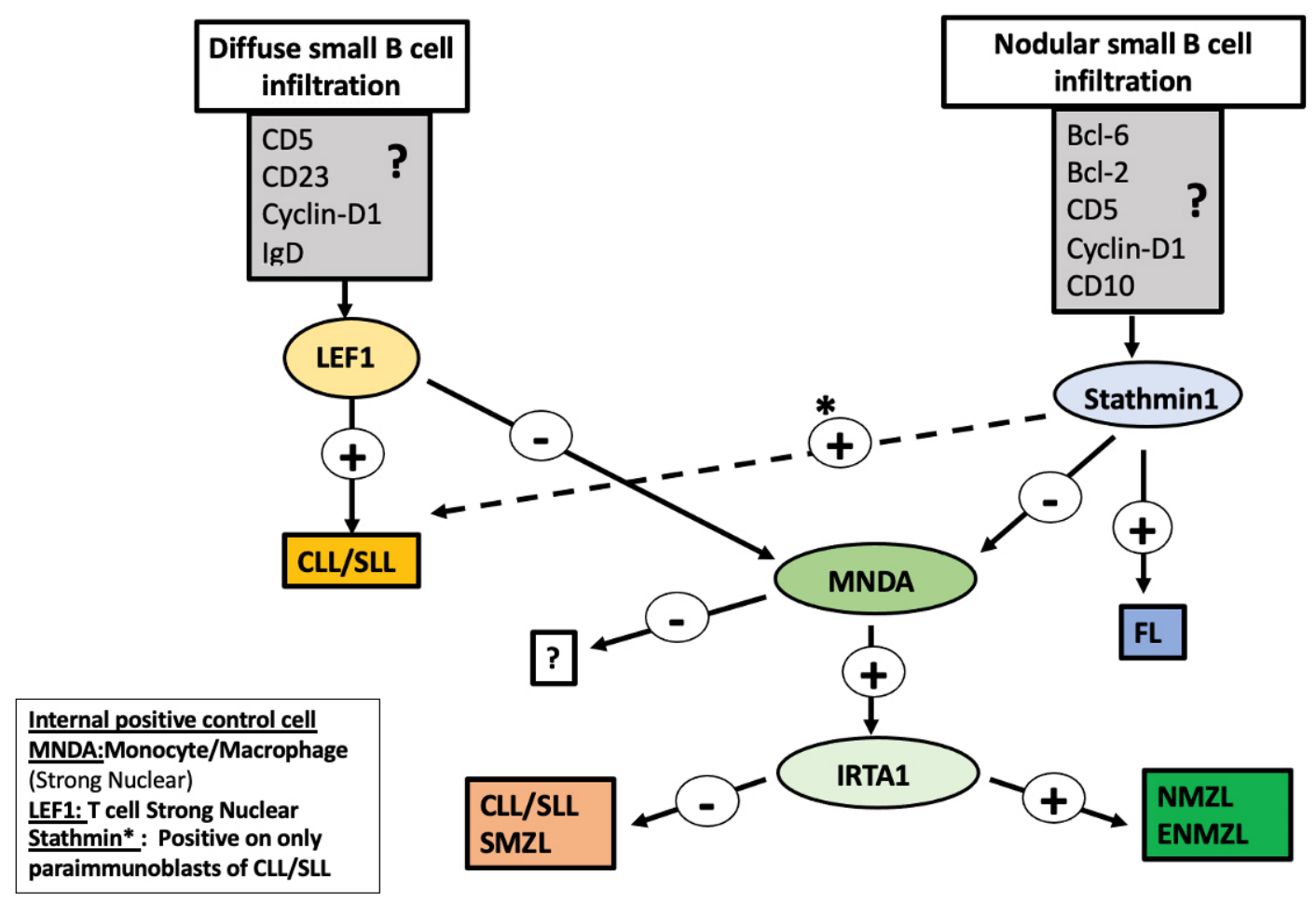

Figure 4. The algorithm of expression of the markers in SBCLs in our series is summarized regarding differential diagnosis.

CLL/SLL: Chronic lymphocytic leukemia/small lymphocytic lymphoma; FL: follicular lymphoma; SMZL: splenic marginal zone lymphoma; NMZL: nodal marginal zone lymphoma; ENMZL: extranodal marginal zone lymphoma; LEF1: lymphoid enhancer-binding factor-1; MNDA: myeloid cell nuclear differentiation antigen; IRTA1: immune receptor translocation-associated protein 1; STMN1: stathmin 1.

expression of MNDA in CLL samples ( $p=0.019)$. Similar results have been previously reported with expression being related to better prognosis [29].

CD27 is expressed on activated and memory B-cells of the marginal zone, B1-cells, and memory T-cells and it is highly expressed on plasma cells. In parallel with MNDA, CD27 expression was statistically significant in MZLs. This finding is logical for two reasons. First, the marginal zone region may contain plasma cells that express CD27 [30]. Second, CD27positive post-germinal center memory cells are located in this area [31]. It is known that the majority of B lymphocytes in marginal zone localization are IgM-positive, IgD-negative, and CD27-positive. High expression of CD27 and MNDA in MZLs can be considered as a hallmark of memory B-cells. While MNDA expression was not observed in plasma cells accompanying neoplastic lymphocytes, CD27 has a role in plasma cell differentiation and may be widely expressed.

Selective IRTA1-expressing B-cells in normal tonsils are located in intraepithelial and subepithelial areas as well as within the dome epithelial cells of Peyer patches. IRTA1-expressing memory B-cells also express CD27 in the lymph nodes [32]. In our study, IRTA1 expression was found to be statistically significant in NMZL and ENMZL cases, as was reported in the literature. One study indicated that the IRTA1 antibody is useful for distinguishing MALT lymphoma from other low-grade B-cell lymphomas [16]. Although it is a useful marker for identifying $M Z L$, according to our results its sensitivity is low. Although different positive cut-off values are given in the literature, it is expressed at a higher rate in MZLs, and especially in ENMZL and NMZL cases. Similarly, IRTA1 expression was not seen in concomitant plasma cells [17]. These results indicate that it can be used as a marginal zone marker, especially for distinction of FL from MZLs in small biopsies or in cases in which cellular details cannot be assessed due to artifacts [8].

The diagnosis of $\mathrm{FL}$ is based on immunohistological evidence of neoplastic germinal center cells expressing Bcl-2, Bcl-6, and CD10 together with molecular detection of the frequently seen $\mathrm{t}(14 ; 18)$ abnormality. Immunohistochemistry and morphology are helpful for the differential diagnosis. The differences of the sensitivity of Bcl-2 antibody clones may also sometimes create diagnostic challenges. A reliable germinal center B-cell marker would be helpful in circumstances where fluorescence in situ hybridization is not available. In our study, we confirmed the significance of STMN1 expression in FL cases compared to other SBCLs. Similar to the findings in the study by Marafioti et al. [18], STMN1 seems to be a candidate marker for solving the 
differential diagnostic problems for FL. Similarly, as given in the supplementary list of the series of Marafioti et al. [18], we observed STMN1 expression in 12 of 21 CLL cases, but selectively on paraimmunoblastic cells. Similar to CLL, STMN1 expressions in the other lymphoma cases in our study were strictly related to transformed cells. The two of our FL cases without STMN1 expression were of low grade (grade 1-2) with very low proliferation.

\section{Study Limitations}

MYD88 mutation was only confirmed for half of the LPL/WM cases due to limitations inherent in the archived bone marrow biopsy specimens. The diagnosis of LPL/WM was confirmed with either flow cytometry or immunohistochemistry and clinical characteristics in cases where molecular confirmation was not possible.

\section{Conclusion}

New markers are helpful for the differential diagnosis of SBCL cases in which specific molecular changes could not be identified or limitations are present due to the size of the biopsy materials. LEF1 and STMN1 are sensitive and specific markers for $\mathrm{CLL} / \mathrm{SLL}$ and $\mathrm{FL}$, respectively. MNDA and IRTA1 are useful markers for suggesting the marginal zone phenotype. The sensitivity of IRTA1 is lower compared to that of MNDA, but when it is expressed, it may be helpful in the exclusion of SMZL from other MZL entities. Our results suggest that LEF1 for CLL/SLL and STMN1 for FL are reliable markers. LEF1, MNDA, STMN1, and IRTA1 are helpful together with other routinely used immunohistochemical markers in a diagnostic algorithm considering their limitations.

Acknowledgments: This research project was supported by the Ankara University Scientific Research Projects Fund (project no. 14L0230001). The microscopic materials of this study were prepared using the digital pathology system supported by the Ankara University Research Fund (project no. 14A0230003).

\section{Ethics}

Ethics Committee Approval: All patients provided written informed consent. All authors ensured that the work described was carried out in accordance with the Code of Ethics of the World Medical Association (Declaration of Helsinki). The Ethics Committee of the Ankara University Faculty of Medicine granted approval for this study (approval number: I3-596-14).

\section{Authorship Contributions}

Concept: H.K., I.K.; Data Collection or Processing: H.K., S.Y., I.K., M.M., M.Ö.; Analysis or Interpretation: C.A.; Literature Search: G.K.
Conflict of Interest: No conflict of interest was declared by the authors.

Financial Disclosure: The authors declared that this study received no financial support.

\section{References}

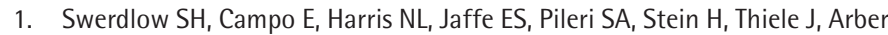
DA, Hasserjian RP, Le Beau MM, Orazi A, Siebert R. WHO Classification of Tumours of Haematopoietic and Lymphoid Tissues, 4th Edition. Lyon, IARC, 2017.

2. Challagundla P, Jorgensen JL, Kanagal-Shamanna R, Gurevich I, Pierson DM, Ferrajoli A, Reyes SR, Medeiros $\sqcup$, Miranda RN. Utility of quantitative flow cytometry immunophenotypic analysis of CD5 expression in small B-cell neoplasms. Arch Pathol Lab Med 2014;138:903-909.

3. Du MQ. MALT lymphoma: genetic abnormalities, immunological stimulation and molecular mechanism. Best Pract Res Clin Haematol 2017;30:13-23.

4. Spina V, Rossi D. Molecular pathogenesis of splenic and nodal marginal zone lymphoma. Best Pract Res Clin Haematol 2017;30:5-12.

5. Briggs RC, Kao WY, Dworkin LL, Briggs JA, Dessypris EN, Clark J. Regulation and specificity of MNDA expression in monocytes, macrophages, and leukemia/B lymphoma cell lines. J Cell Biochem 1994;56:559-567.

6. Miranda RN, Briggs RC, Shults K, Kinney MC, Jensen RA, Cousar JB. Immunocytochemical analysis of MNDA in tissue sections and sorted normal bone marrow cells documents expression only in maturing normal and neoplastic myelomonocytic cells and a subset of normal and neoplastic B lymphocytes. Hum Pathol 1999;30:1040-1049.

7. Kanellis G, Roncador G, Arribas A, Mollejo M, Montes-Moreno S, Maestre L, Campos-Martin Y, Rios Gonzalez JL, Martinez-Torrecuadrada JL, SanchezVerde L, Pajares R, Cigudosa JC, Martin MC, Piris MA. Identification of MNDA as a new marker for nodal marginal zone lymphoma. Leukemia 2009;23:1847-1857.

8. van den Brand M, Mathijssen JJ, Garcia-Garcia M, Hebeda KM, Groenen PJ, Falini B, Serrano S, van Krieken JH. Immunohistochemical differentiation between follicular lymphoma and nodal marginal zone lymphoma-combined performance of multiple markers. Haematologica 2015;100:e358360.

9. Agematsu K, Hokibara S, Nagumo H, Komiyama A. CD27: A memory B-cell marker. Immunol Today 2000;21:204-206.

10. Lohneis $P$, Wienert $S$, Klauschen F, Ullrich A, Anagnostopoulos I, Johrens K. Marginal zone lymphomas with monocytoid morphology express T-bet and are associated with a low number of T cells in extranodal locations. Leuk Lymphoma 2014;55:143-148.

11. Franco V, Florena AM, Ascani S, Paulli M, Salvato M, Pileri SA. CD27 distinguishes two phases in bone marrow infiltration of splenic marginal zone lymphoma. Histopathology 2004;44:381-386.

12. Khan NI, Bendall $\amalg$. Role of WNT signaling in normal and malignant hematopoiesis. Histol Histopathol 2006;21:761-774.

13. Reya T, O'Riordan M, Okamura R, Devaney E, Willert K, Nusse R, Grosschedl R. Wnt signaling regulates $B$ lymphocyte proliferation through a LEF-1 dependent mechanism. Immunity 2000;13:15-24.

14. Tandon B, Peterson L, Gao J, Nelson B, Ma S, Rosen S, Chen YH. Nuclear overexpression of lymphoid-enhancer-binding factor 1 identifies chronic lymphocytic leukemia/small lymphocytic lymphoma in small B-cell lymphomas. Mod Pathol 2011;24:1433-1443.

15. Menter T, Dirnhofer S, Tzankov A. LEF1: a highly specific marker for the diagnosis of chronic lymphocytic B cell leukaemia/small lymphocytic B cell lymphoma. J Clin Pathol 2015;68:473-478. 
16. Ikeda Jl, Kohara M, Tsuruta Y, Nojima S, Tahara S, Ohshima K, Kurashige M, Wada N, Morii E. Immunohistochemical analysis of the novel marginal zone B-cell marker IRTA1 in malignant lymphoma. Hum Pathol 2017;59:70-79.

17. Falini B, Agostinelli C, Bigerna B, Pucciarini A, Pacini R, Tabarrini A, Falcinelli F, Piccioli M, Paulli M, Gambacorta M, Ponzoni M, Tiacci E, Ascani S, Martelli MP, Dalla Favera R, Stein H, Pileri SA. IRTA1 is selectively expressed in nodal and extranodal marginal zone lymphomas. Histopathology 2012;61:930941.

18. Marafioti T, Copie-Bergman C, Calaminici M, Paterson JC, Shende VH, Liu $H$, Baia M, Ramsay AD, Agostinelli C, Briere J, Clear A, Du MQ, Piccaluga PP, Masir N, Nacheva EP, Sujobert P, Shanmugam K, Grogan TM, Brooks SP, Khwaja A, Ardeshna K, Townsend W, Pileri SA, Haioun C, Linch D, Gribben JG, Gaulard P, Isaacson PG. Another look at follicular lymphoma: immunophenotypic and molecular analyses identify distinct follicular lymphoma subgroups. Histopathology 2013;62:860-875.

19. Verdanet $E$, Dereure O, Rene C, Tempier A, Benammar-Hafidi A, Gallo M, Frouin E, Durand L, Gazagne I, Costes-Martineau V, Cacheux V, Szablewski V. Diagnostic value of STMN1, LM02, HGAL, AID expression and 1p36 chromosomal abnormalities in primary cutaneous B cell lymphomas. Histopathology 2017;71:648-660.

20. Bob R, Falini B, Marafioti T, Paterson JC, Pileri $S$, Stein $H$. Nodal reactive and neoplastic proliferation of monocytoid and marginal zone $B$ cells: an immunoarchitectural and molecular study highlighting the relevance of IRTA1 and T-bet as positive markers. Histopathology 2013;63:482-498.

21. Swerdlow SH, Kuzu I, Dogan A, Dirnhofer S, Chan JK, Sander B, Ott G, Xerri L, Quintanilla-Martinez $L$, Campo $E$. The many faces of small $B$ cell lymphomas with plasmacytic differentiation and the contribution of MYD88 testing. Virchows Arch 2016;468:259-275.

22. Metcalf RA, Monabati A, Vyas M, Roncador G, Gualco G, Bacchi CE, Younes $S F$, Natkunam $Y$, Freud AG. Myeloid cell nuclear differentiation antigen is expressed in a subset of marginal zone lymphomas and is useful in the differential diagnosis with follicular lymphoma. Hum Pathol 2014;45:17301736.

23. Lin $\mathrm{P}$, Hao $\mathrm{S}$, Handy $\mathrm{BC}$, Bueso-Ramos $C E$, Medeiros $\sqcup$. Lymphoid neoplasms associated with IgM paraprotein: a study of 382 patients. Am J Clin Pathol 2005;123:200-205.
24. van den Brand $M$, van Krieken JH. Recognizing nodal marginal zone lymphoma: recent advances and pitfalls. A systematic review. Haematologica 2013;98:1003-1013.

25. Duong Van Huyen JP, Molina T, Delmer A, Audouin J, Le Tourneau A, Zittoun $R$, Bernadou A, Diebold J. Splenic marginal zone lymphoma with or without plasmacytic differentiation. Am J Surg Pathol 2000;24:1581-1592.

26. Gutierrez A Jr, Arendt BK, Tschumper RC, Kay NE, Zent CS, Jelinek DF. Differentiation of chronic lymphocytic leukemia B cells into immunoglobulin secreting cells decreases LEF-1 expression. PLoS One 2011;6:e26056.

27. Wang Z, Cook JR. IRTA1 and MNDA expression in marginal zone lymphoma: utility in differential diagnosis and implications for classification. Am J Clin Pathol 2019;151:337-343.

28. Manohar V, Peerani R, Tan B, Gratzinger D, Natkunam Y. Myeloid cell nuclear differentiation antigen (MNDA) positivity in primary follicles: potential pitfall in the differential diagnosis with marginal zone lymphoma. Appl Immunohistochem Mol Morphol 2020;28:384-388.

29. Joshi AD, Hegde GV, Dickinson JD, Mittal AK, Lynch JC, Eudy JD, Armitage JO, Bierman PJ, Bociek RG, Devetten MP, Vose JM, Joshi SS. ATM, CTLA4, MNDA, and HEM1 in high versus low CD38 expressing B-cell chronic lymphocytic leukemia. Clin Cancer Res 2007;13:5295-5304.

30. Nutt SL, Hodgkin PD, Tarlinton DM, Corcoran LM. The generation of antibody-secreting plasma cells. Nat Rev Immunol 2015;15:160-171.

31. Agematsu $K$, Nagumo $H$, Yang FC, Nakazawa T, Fukushima $K$, Ito $S$, Sugita $K$, Mori T, Kobata T, Morimoto C, Komiyama A. B cell subpopulations separated by $C D 27$ and crucial collaboration of $\mathrm{CD}_{2} 7^{+} \mathrm{B}$ cells and helper T cells in immunoglobulin production. Eur J Immunol 1997;27:2073-2079.

32. Falini $B$, Tiacci $E$, Pucciarini A, Bigerna B, Kurth J, Hatzivassiliou G, Droetto S, Galletti BV, Gambacorta M, Orazi A, Pasqualucci L, Miller I, Kuppers R, Dalla-Favera $R$, Cattoretti G. Expression of the IRTA1 receptor identifies intraepithelial and subepithelial marginal zone B cells of the mucosaassociated lymphoid tissue (MALT). Blood 2003;102:3684-3692. 